\title{
UNDUE INFLUENCE: TOWARDS A UNIFYING CONCEPT OF UNCONSCIONABLITY?
}

\author{
Mark Pawlowski *
}

\section{ABSTRACT}

The article argues for an assimilation of the related doctrines of undue influence and unconscionable dealings under one common umbrella of unconscionability. The interrelationship between unconscionable bargains and undue influence under English law is considered in some detail, as well as developments in other Commonwealth jurisdictions, notably, in Canada, Australia and New Zealand. After examining the views of several academic commentators, the conclusion is that such an assimilation would do much to rationalise and simplify current English law. If, however, the English courts are reluctant to undertake what is perceived to be essentially a function of Parliament in developing the law, serious thought should be given to rationalising this area of law by means of legislative intervention.

\section{INTRODUCTION}

To what extent would it be desirable to subsume the doctrine of undue influence under a wider notion of unconscionability? Lord Denning MR, in the well-known case of Lloyds Bank Ltd v Bundy, ${ }^{1}$ attempted to bring together the law on duress, unconscionable bargains and undue influence under the one umbrella of "inequality of bargaining power". In his formulation, the concepts unconscionability and exertion of excessive power or coercion by a stronger party over a weaker one, were to be regarded as key elements in establishing the basis for equity's intervention.

Unconscionability, however, as a unifying doctrine in the context of undue influence and unconscionable bargains has found little support in

\footnotetext{
* LLB (Hons), BCL (Oxon), ACIArb, SFHEA, Barrister, Professor of Property Law, School of Law, University of Greenwich.

${ }^{1}$ [1974] 3 All ER 757 (CA). See also, Arrale v Costain Civil Engineering Ltd [1976] Lloyd's Rep 98 (CA); Levison v Patent Steam Carpet Cleaning Co [1978] QB 69 (CA); Avon Finance Co Ltd v Bridger [1985] 2 All ER 281 (CA), where Lord Denning MR had occasion to repeat his formulation.
} 
the English case law on the ground that the need for a more general formulation of principle (such as that enunciated by Lord Denning in Bundy) is a matter of legislative reform rather than judicial development. ${ }^{2}$ However, not all judges have agreed. In Credit Lyonnais Bank Nederland $N V v$ Burch, ${ }^{3}$ Nourse LJ appears to have accepted ${ }^{4}$ that unconscionable bargains and cases involving undue influence may come under the general heading of "inequality of bargaining power", citing Balcombe LJ's judgment in the earlier case of Backhouse $v$ Backhouse. ${ }^{5}$ Again, in Langton $v$ Langton, ${ }^{6} \mathrm{Mr}$ AWH Charles QC (sitting as a deputy High Court judge) opined that the rationale underlying the doctrine of unconscionable bargains was closely linked to that behind a class $2 b$ presumed undue influence relationship. He stated: ${ }^{7}$

\begin{abstract}
“... it seems to me that the 'unconscionable bargain' cases which arise as to particular transactions with poor and ignorant people could, and should, now be treated on the basis of, or by analogy to, the undue influence cases as one of the relationships where in all the circumstances a presumption that the transaction was procured by undue or improper influence arises and therefore has to be justified by the purchaser."
\end{abstract}

In the deputy judge's view, what underlies equity in both the presumed undue influence and unconscionable bargain cases "is the identification of a relationship which gives rise to a presumption that the donor, or recipient, should have the onus of establishing the righteousness of the transaction." 8

\title{
3 UNCONSCIONABILITY IN OTHER AREAS OF EQUITY
}

There have, undoubtedly, been other areas in equity which have benefitted from a rationalisation of principles under the one umbrella of unconscionability. An obvious example has been the willingness of the

\footnotetext{
${ }^{2}$ See National Westminster Bank plc v Morgan [1985] 1 All ER 821 (HL) 830 (Lord Scarman).

3 [1997] 1 All ER 144 (CA).

${ }^{4}$ Ibid 151.

5 [1978] 1 All ER 1158 (CA) 1166.

${ }^{6}$ [1995] 2 FLR 890.

${ }^{7}$ Ibid 908.

${ }^{8}$ Langdon (n 6) 909
} 
English courts to adopt a broader-based doctrine of unconscionability as underlying proprietary estoppel claims and the personal liability of a stranger to a trust who has knowingly received trust property in breach of trust. The decisions in Gillett $v$ Holt,${ }^{9}$ Jennings $v$ Rice ${ }^{10}$ and Campbell $v$ Griffin $^{11}$ in the context of proprietary estoppel and Bank of Credit and Commerce International (Overseas) Ltd v Akindele ${ }^{12}$ on the subject of receipt liability demonstrate the judiciary's growing recognition that the concept of unconscionability provides a useful mechanism for affording equitable relief against the strict insistence on legal rights or unfair and oppressive conduct.

In the context of imperfect gifts, the well-known principle in Milroy $v$ Lord $^{13}$ establishes that an attempted transfer of land or personalty, which does not meet the formal requirements of writing and registration, may take effect in equity provided that the transferor has done everything required of him and the only steps remaining to be done are to be performed by a third party. In these circumstances, the transferor will be treated as holding the legal title to the property as bare trustee for the transferee ${ }^{14}$ However, more recently, the Court of Appeal in Pennington $v$ Waine $^{15}$ decided that where the donor had manifested an immediate and irrevocable intention to donate shares to another and had instructed her agent to execute the transfer, the donor would not be permitted to deny the interest acquired by the donee. Significantly, the transfer of shares in this case was treated as complete because it would be unconscionable for the transferor to recall the gift. The decision has not been without its critics not least because it is argued that the effectiveness of transfers of property should not be determined by the uncertainties associated with whether a court considers that it would be unconscionable for the donor to change his mind and seek to recall the gift. ${ }^{16}$ Other commentators, on the other hand, have welcomed this development emphasising the flexibility and

\footnotetext{
9 [2001] Ch 210 (CA).

${ }^{10}$ [2002] EWCA Civ 159 (CA).

11 [2001] WTLR 981 (CA). See also, most recently, Ottey v Grundy [2003] EWCA Civ 1176.

12 [2000] 4 All ER 221 (CA).

13 (1862) 31 LJ Ch 798 (HL).

${ }^{14}$ Re Rose [1952] Ch 499 (CA), (transfer of shares). See also, Mascall v Mascall (1984) 49 P \& CR 119, (transfer of registered land).

15 [2002] 1 WLR 2075 (CA).

${ }^{16}$ See M Halliwell, 'Perfecting Imperfect Gifts and Trusts: Have We Reached the End of the Chancellor's Foot?' [2003] Conv 192.
} 


\section{UNDUE INFLUENCE: TOWARDS A UNIFYING CONCEPT OF UNCONSCIONABLITY?}

conceptual clarity that an approach based on unconscionability brings over established equitable principles. ${ }^{17}$ In terms of clarity, the decision of Biggs $\mathrm{J}$ in Curits $v$ Pullbrook ${ }^{18}$ has sought to narrow the concept of unconscionability in this context by treating the question as essentially one of detrimental reliance by the donee which binds the conscience of the donor so as to justify the imposition of a constructive trust. In his Lordship's view, the donee in Pennington had agreed to become a director of the subject company upon an assumption that he had received an effective gift of shares in it. This would suggest that the unconscionability test in imperfect gift cases is simply another example of the operation of proprietary estoppel.

Where the parties have entered into an arrangement involving the purchase of property by one of them, that party may be required to hold the property on constructive trust for both of them if it is considered to be unconscionable for the party acquiring the property to deny that the other party has an equitable interest in the property. ${ }^{19}$ The three key ingredients to raise an equity of this kind are: (1) the existence of an arrangement between the parties that beneficial ownership in the property is to be shared; (2) the claimant must have relied on the arrangement by doing (or omitting to do) something which either confers an advantage on the defendant or is detrimental to the ability of the claimant to acquire the property on equal terms; and (3) the defendant must have acted inconsistently with the arrangement. Significantly, it is the acting inconsistently with the arrangement, once the claimant has relied on it, that renders the defendant's conduct unconscionable and which triggers the imposition of a constructive trust. ${ }^{20}$

The doctrine of secret trusts evolved originally on the basis of not allowing a statute to be used as an instrument of fraud so as to deny the validity of a secret trust for lack of writing. ${ }^{21}$ Enforcement of the secret

\footnotetext{
17 See J Garton, 'The Role of the Trust Mechanism in the Rule in Re Rose' [2003] Conv 364.

18 [2011] EWHC 167 (Ch) [43], [46]. See also, Zeital v Kaye [2010] EWCA Civ 159 (CA) [44].

${ }^{19}$ See Pallant $v$ Morgan [1953] Ch 43.

20 See Banner Homes Group plc v Luff Developments Ltd [2000] Ch 371; Yaxley $v$ Gotts [2000] Ch 162; Herbert v Doyle [2010] EWCA Civ 1095; Dowding v Matchmore Ltd [2016] EWCA Civ 1233; Generator Developments LPP v Lidl UK GmbH [2018] EWCA Civ 396.

21 See McCormick v Grogan (1869) LR 4 HL 82, 88-89, 97; Blackwell v Blackwell [1929] AC 318 [335].
} 
trust does not, however, depend on the actual fraudulent enrichment of the secret trustee - instead, it can be supported on the basis of a general fraud committed upon the testator and the secret beneficiaries by reason of the failure to observe the intentions of the testator and the destruction of the beneficial interests of the secret beneficiaries. In other words, the emphasis is on potential not actual wrongdoing. The better view, therefore, is that the enforcement of both fully and half-secret trusts rests on the principle of enforcing equitable obligations binding the secret trustee's conscience. ${ }^{22}$ Given that secret trusts are enforced to prevent fraud in this wider sense, it is then natural to characterise such trusts as constructive trusts falling within the exception to the requirement of writing under s.53(2) of the Law of Property Act 1925. The constructive trust is imposed on the secret trustee because in good conscience he is required to hold the property on trust for the secret beneficiary. Equity will not permit the lack of writing to defeat not only the wishes of the testator, but also undermine the expectations of the secret beneficiary. In Re Cleaver, ${ }^{23}$ Nourse $\mathrm{J}$ characterised secret trusts as constructive trusts. In Kasperbauer $v$ Griffith ${ }^{24}$ the Court of Appeal accepted that, in secret trust cases, equity acts to prevent fraud or unconscionable conduct by imposing a constructive trust on the secret trustee. In Gillett $v$ Holt, ${ }^{25}$ Roberty Walker LJ acknowledged that secret trusts are enforced in order to prevent unconscionable conduct.

Mutual wills arise where two parties (usually husband and wife) make identical wills, pursuant to a legally binding agreement, in each other's favour on terms that the survivor will not revoke his will without the consent of the other. Normally, revocation will give rise to a claim for breach of contract during the joint lives of the parties, but when one party has died, if the survivor revokes, the deceased can no longer maintain an action for breach of contract. Instead, a constructive trust is imposed in equity on the survivor from the moment of the death of the first to die for the benefit of those entitled under the deceased's estate in order to prevent an equitable fraud. Significantly, for present purposes, the constructive trust arises by operation of law in response to the survivor's unconscionable conduct in not leaving the property as the parties had

\footnotetext{
22 See Ottaway v Norman [1972] Ch 698, 711; Ledgerwood v Perpetual Trustee Co Ltd (1997) 41 NSWLR 532.

${ }^{23}$ [1981] 1 WLR 939, 947.

24 [2000] WTLR 333.

25 [2001] Ch 210, 228, referring also to mutual wills where equity has intervened to prevent unconscionable conduct.
} 
agreed. ${ }^{26}$ The unconscionability, in these circumstances, arises because the other party has relied on the survivor's promise.

\section{UNDUE INFLUENCE}

\subsection{Modern categorisation}

The English courts have traditionally divided the cases on undue influence into two distinct categories, namely, those involving (1) actual; or (2) presumed undue influence. ${ }^{27}$ These two categories were further refined by the House of Lords in the landmark case of Barclays Bank plc $v O^{\prime}$ Brien.$^{28}$ In class 1 cases, it is necessary for the claimant to prove that the wrongdoer exerted undue influence on the complainant to enter into the transaction.

In class 2 cases (involving presumed undue influence), the presumption of undue influence arises when an appropriate relationship exists between the parties. Here, the complainant has to show, initially, that there was a relationship of trust and confidence between the complainant and the wrongdoer of such a nature that it is fair to presume that the wrongdoer abused that relationship in procuring the complainant to enter into the transaction. In this category, therefore, there is no requirement to produce evidence that actual undue influence was exerted in relation to the transaction. The relationship can be established in one of two ways. First, certain types of relationship, as matter of law, raise the presumption of undue influence automatically (class 2a). These include solicitor and client, doctor and patient, and parent and child. Significantly, however, the relationship of husband and wife does not come within this category. Secondly, even if there is no relationship falling within class $2 \mathrm{a}$, the specific relationship between the particular parties may be such as to give rise to the presumption. Here, the complainant must prove the existence of a relationship under which the complainant generally "reposed trust and confidence" in the wrongdoer (class 2b). The relationship of husband and wife falls within this category.

An additional element in the presumed undue influence cases (class 2a and $2 \mathrm{~b}$ ) has been the need to show that the transaction was manifestly

\footnotetext{
${ }^{26}$ See Ollins $v$ Walters [2009] Ch 212 [37] (Mummery LJ).

${ }^{27}$ See Allcard $v$ Skinner (1887) 36 Ch D 145.

28 [1993] 4 All ER 417 (HL), adopting the two-fold classification set out in Bank of Credit and Commerce International SA v Aboody [1992] 4 All ER 955 (CA).
} 
disadvantageous to the complainant. ${ }^{29}$ The requirement was first introduced by the House of Lords in National Westminster Bank plc $v$ Morgan $^{30}$ and has since been criticised both academically and judicially. In CIBC Mortgages plc $v$ Pitt, ${ }^{31}$ for example, Lord Browne-Wilkinson pointed out that this requirement was at odds with the line of cases involving abuse of confidence where the onus is on the fiduciary to show that the transaction is a fair one. Because of the obvious overlap between such relationships and those in which undue influence is presumed, a cogent argument exists for abandoning the requirement of manifest disadvantage altogether in undue influence cases. Instead, the onus would be on the person taking advantage of the claimant to show the "righteousness" of the transaction. Unfortunately, the abuse of confidence cases were not cited to the House of Lords in Morgan and so the interaction between the two sets of principles were not considered.

Although subsequently the House of Lords in Royal Bank of Scotland $v$ Etridge $(\mathrm{No} 2)^{32}$ recognised that the requirement of manifest disadvantage had been the subject of some criticism, it declined to depart from its earlier decision in Morgan on this point. It reiterated that the burden of proving an allegation of undue influence rested upon the person who claims to have been wronged. The evidence required to discharge that burden of proof depended on a variety of factors, including the nature of the alleged undue influence, the personality of the parties, their relationship, the extent to which the transaction cannot readily be accounted for by ordinary motives of ordinary persons in that relationship and all the circumstances of the case. Normally, proof that the complainant placed trust and confidence in the other party in relation to the management of the complainant's financial affairs, coupled with a transaction which calls for explanation, would be sufficient to discharge the burden of proof. This would then shift the evidential burden onto the wrongdoer to produce evidence to counter the inference of undue influence.

\footnotetext{
${ }^{29}$ See CIBC Mortgages plc v Pitt [1993] 4 All ER 433 (HL).

${ }^{30}$ [1985] AC 686 (HL).

31 [1993] 4 All ER 433 (HL). See also, Barclays Bank plc v Coleman [2001] QB

20 (CA) 30-32 (Nourse LJ).

32 [2002] AC 773 (HL).
} 


\subsection{Liability of lending institutions}

In Barclays Bank $v O^{\prime}$ Brien, ${ }^{33}$ the House of Lords concluded that a wife's right to have a transaction set aside as against her husband on the grounds of her husband's undue influence will be enforceable against a bank (or other creditor) if either the husband was acting as the bank's agent, or the bank had actual or constructive notice of the facts giving rise to her equity. Undoubtedly, cases where the husband is acting as the bank's agent are rare, so in the majority of claims the question has been whether the bank actually knows of the wife's equity (actual notice) or would have discovered it by taking reasonable steps (constructive notice). The same test is applied to all other relationships of trust and confidence including emotional relationships between cohabitees. However, this formulation has since been interpreted in Etridge to mean that a lender will automatically be put on inquiry where a wife stands surety for her husband's debts. Indeed, the lender is put on inquiry in every case where the relationship between surety and the debtor is non-commercial. ${ }^{34}$

If the wife establishes a prima facie inference of undue influence, the burden then passes to the lender to show that it had taken reasonable steps to satisfy itself that the wife's consent had been properly obtained. In Etridge, the House of Lords concluded that a personal meeting with the wife was not the only way a bank could discharge its obligation to bring home to the wife the risks she is running. It was not unreasonable for a lender to prefer that this task should be undertaken by an independent legal adviser. Normally, therefore, it will be reasonable for a bank to rely upon the confirmation from a solicitor, acting for the wife, that he has advised her appropriately.

\section{UNCONSCIONABLE BARGAINS}

\subsection{The traditional formulation}

The classic formulation of this doctrine is to be found in the judgment of Kay $\mathrm{J}$ in Fry $v$ Lane: ${ }^{35}$

"The result of the decisions is that where a purchase is made from a poor and ignorant man at a considerable undervalue, the vendor

\footnotetext{
33 [1993] 4 All ER 417 (HL).

34 Ibid [87].

35 (1888) 40 Ch D 312, 322.
} 
having no independent advice, a Court of Equity will set aside the transaction ... The circumstances of poverty and ignorance of the vendor, and the absence of independent, throw upon the purchaser, when the transaction is impeached, the onus of proving ... that the purchase was 'fair, just and reasonable"".

It has been held that the modern equivalent of "poor and ignorant" is "a member of the lower income group ... less highly educated." 36 This broadening of the class of claimant eligible for relief has increased considerably the potential availability of the doctrine to a wider range of transactions where the terms are unconscionable and the victim did not receive independent legal advice. In Boustany $v$ Piggot ${ }^{37}$ for example, the Privy Council was asked to consider whether, on the facts, a lease should be set aside on the grounds that it was an unconscionable bargain. In the course of his speech, Lord Templeman expressed "general agreement" with the following propositions of law:

It is not sufficient to attract equity's jurisdiction to prove merely that a bargain is hard, unreasonable or foolish. It must be shown to be unconscionable in the sense that "one of the parties to it has imposed the objectionable terms in a morally reprehensible manner, that is to say, in a way which affects his conscience." 38

The word "unconscionable" relates not only to the terms of the bargain, but also to the behaviour of the stronger party, which must be characterised by some moral culpability or impropriety. ${ }^{39}$

Unequal bargaining power (or objectively unreasonable terms) provides no basis for equitable interference in the absence of unconscientious or extortionate abuse of power.

${ }^{36}$ Cresswell v Potter [1978] 1 WLR 255, 257 (Megarry J). See also, Backhouse v Backhouse [1978] 1 All ER 1158 [1165], where a generous interpretation of the phrase "poor and ignorant" was applied to a wife who was not "ignorant" but an "intelligent woman" and "certainly not wealthy". The wife, however, was "ignorant" in the context of property transactions generally and, in particular, the execution of a conveyancing document.

37 (1995) 69 P \& CR 298 (PC). See N Bamforth, 'Unconscionability as a Vitiating Factor' [1995] LMCLQ 538, who considers the decision in Boustany at some length.

38 Multiservice Bookbinding Ltd v Marden [1979] Ch 84, 110 (BrowneWilkinson J).

${ }^{39}$ See Alec Lobb (Garages) Ltd v Total Oil (Great Britain) Ltd [1983] 1 WLR 87, 94-95 (Millett QC) (sitting as a deputy High Court judge). 


\section{UNDUE INFLUENCE: TOWARDS A UNIFYING CONCEPT OF UNCONSCIONABLITY?}

A contract cannot be set aside in equity as an unconscionable bargain against a party who is innocent of actual or constructive fraud. Even if the terms of the contract are unfair in the sense that they are more favourable to one party than the other (i.e., contractual imbalance), equity will not provide relief unless the purchaser is guilty of unconscionable conduct. ${ }^{40}$

It is necessary for the claimant who seeks relief to establish unconscionable conduct, namely, that "unconscientious advantage has been taken of his disabling condition or circumstances." 41

In Fineland Investments Ltd $v$ Pritchard, ${ }^{42} \mathrm{Mr}$ Alison Foster QC reiterated that a court will have little or no sympathy for a complainant who seeks to overturn a transaction merely on the grounds that it is a foolish bargain which has caused distress and subsequent regret. In the words of the deputy judge: ${ }^{43}$

“... equity will not relieve a party from a contract on the ground only that there is contractual imbalance not amounting to unconscionable dealing; the court of Equity requires 'undertones of constructive fraud' for the court to consider rescinding a contract otherwise properly made."

In this case, there was no suggestion that the transactions were necessarily oppressive in overall terms. On the issue of bargaining weakness, whilst it was apparent that the defendant was "not a lady of means", the deputy judge was not prepared to accept that she was under any misapprehension as to the documentation she signed. She had asked "astute questions" and these were fully investigated and answered before she was required to sign. There was also, on the evidence, nothing unconscionable about the company's behaviour towards her. Although she was uncertain as to what she wanted to do (which caused her stress) and she later had regrets about entering into the transaction, this did not amount to oppressive behaviour on the part of the company. A bargain which was merely hard or improvident (which, in any event, was not the case here) was not in itself enough to trigger the doctrine. Although the defendant relied heavily on the Boustany decision, that case was clearly

\footnotetext{
${ }^{40}$ See Hart v O'Connor [1985] AC 1000 (PC) 1017 (Lord Brightman).

${ }^{41}$ Commercial Bank of Australia Ltd v Amadio (1983) 151 CLR 447 (Mason J) (High Court of Australia).

42 [2011] EWHC 113 (Ch). See also, Minder Music Ltd v Sharples [2015] EWHC 1454 (IPEC).

43 Ibid [77]
} 
distinguishable. Unlike Fineland, the proposed new lease was obviously disadvantageous to Miss Pigott since it would itself be renewable at the same (already uncommercial) level of rent for a further 10 year term. In addition, it was apparent that the complainant in Boustany had been largely duped into entering into the new lease without any proper legal advice and unaware of the true market rental value of the premises. In this connection, it was significant that the new lease had been executed in the absence of Miss Pigott's cousin who would normally have acted on her behalf in relation to her properties. The inference here was that Mrs Boustany and her husband had prevailed upon Miss Pigott to execute a new lease which they knew her agent would never have agreed.

\subsection{Interrelationship between unconscionable bargains and undue influence}

Significantly, several English cases have alluded to the interrelationship between the two doctrines of unconscionable bargains and undue influence. In Credit Lyonnais Bank Nederland $N V v$ Burch, ${ }^{44} \mathrm{a}$ case involving a claim of undue influence brought by a junior employee against her employer, both Nourse and Millett LJJ suggested that the claimant might have brought an alternative claim directly against the bank to set aside the charge on the grounds of unconscionability. The transaction was manifestly disadvantageous to her and the bank had not explained the potential extent of her liability, nor had she received independent advice. Nourse LJ, whilst accepting that the case was not pleaded on the basis of an unconscionable bargain, nevertheless stated that "the unconscionability of the transaction remains of direct materiality to the case based on undue influence." ${ }^{45}$ Indeed, in his view, the transaction was "so harsh and unconscionable as to make it hardly necessary for a court of equity to rely on [Barclays Bank plc v O'Brien $]^{46}$ as a basis for avoiding the transaction" ${ }^{47}$ Millett LJ also alluded to the similarities between the two doctrines and concluded that, if the claimant had sought to have the transaction set aside as a harsh and unconscionable bargain, she would have to show "not only that the terms of the transaction were harsh and oppressive, but that one of the parties to it has imposed the objectionable terms in a morally reprehensible manner, that

\footnotetext{
44 [1997] 1 All ER 144 (CA).

45 Ibid 151.

46 [1993] 4 All ER 417 (HL).

47 [1997] 1 All ER 144 (CA) 146.
} 


\section{UNDUE INFLUENCE: TOWARDS A UNIFYING CONCEPT OF UNCONSCIONABLITY?}

is to say, in a way which affects his conscience." 48 The recognition in Burch that the O'Brien principle is an application of unconscionability has prompted several academic writers to suggest that the true basis of the decision was not the absence of the claimant's real consent (i.e. undue influence) but the unconscionable conduct on the part of the bank in accepting a transaction which was so heavily unbalanced. ${ }^{49}$

The Court of Appeal was given a further opportunity to consider the interaction between undue influence and unconscionable bargains in Portman Building Society $v$ Dusangh ${ }^{50}$ What is particularly interesting in Ward LJ's judgment in this case is his open recognition that unconscionable conduct was a vitiating factor, similar to undue influence, and that the doctrine of notice (as explained in O'Brien) could apply in this context, so as to bind the lender in the same way as in a case involving undue influence. Significantly, his Lordship relied on a passage in Lord Browne-Wilkinson's speech in $O^{\prime}$ Brien $^{51}$ where he stated that a wife, who has been induced to stand as surety for her husband's debts "by his undue influence, misrepresentation or some other legal wrong" had an equity as against him to set aside the transaction. In his view, unconscionable conduct was "some other legal wrong" and, therefore, the principle in O'Brien on the issue of notice and third parties was equally applicable in cases involving unconscionable bargains. His Lordship also cited the following extract from Millett LJ's judgment in Burch $^{52}$ where, as noted earlier, the similarities between the two jurisdictions to set aside unconscionable bargains and transactions obtained by undue influence were highlighted:

"In either case it is necessary to show that the conscience of the party who seeks to uphold the transaction was affected by notice, actual or constructive, of the impropriety by which it was obtained by the intermediary..."

\footnotetext{
48 Ibid 153.

49 See for example, M Chen-Wishart, 'The O'Brien Principle and Substantive Unfairness' [1977] CLJ 60, 63.

50 [2000] 2 All ER (Comm) 221.

51 [1994] 4 All ER 417 (HL) 428.

52 [1997] 1 All ER 144 (CA) 153.
} 


\subsection{Does the doctrine apply to gifts?}

It is not clear whether the doctrine of unconscionable bargains applies to gifts. In Langton $v$ Langton, ${ }^{53} \mathrm{Mr}$ AWH Charles QC (sitting as a deputy High Court judge) set aside a deed of gift procured by actual/presumed undue influence. It was not, therefore, strictly necessary for him to consider a further ground for setting aside the gift, namely, that it constituted an unconscionable bargain. The deputy judge, however, opined that, if the doctrine applied to gifts, it would mean that, in the case of all gifts by poor and ignorant persons without independent legal advice, the onus of proving that the gift was fair, just and reasonable would be placed on the recipient. That, in his view, would be a surprising result. Moreover, the formulation of the doctrine as expressed by Kay in in Fry $v$ Lane was limited to purchases of property and the description "fair, just and reasonable" in that case was a phrase that applied to bargains and not gifts. In his judgment, the rationale behind the development of the doctrine of unconscionable bargains was to protect people who were in need of money from being taken advantage of by persons prepared to provide it for an exorbitant consideration. It did not, therefore, apply to gifts which was a different type of disposition and one where the donor was, by definition, not seeking a return. As the deputy judge conceded, however, the doctrine has been applied to an unconscionable transaction which, although described and treated as a bargain, was in effect a gift. ${ }^{54}$. Moreover, the view taken in Langton does not accord with Commonwealth authority. In Wilton $v$ Farnworth ${ }^{55}$ the claimant was deaf, poorly educated and dull witted. His stepson persuaded him to sign various documents allowing the former to apply for letters of administration to the claimant's wife's estate and releasing his interest therein to him. The High Court of Australia had no difficulty in setting aside the transaction as an unconscionable dealing. Rich J stated: ${ }^{56}$

“ ... the jurisdiction of courts of equity is based upon unconscientious dealing. It has always been considered unconscientious to retain the advantage of a voluntary disposition

\footnotetext{
53 [1995] 2 FLR 890.

${ }^{54}$ See Cresswell v Potter [1978] 1 WLR 244, 259 (Megarry J): "what was done by the release was, in substance, that a gift was made by a wife who was being divorced to the husband who was divorcing her".

55 (1948) 76 CLR 646 (High Court of Australia).

56 Ibid 655.
} 
of a large amount of property improvidently made by an alleged donor who did not understand the nature of the transaction and lacked information of material facts such as the nature and extent of the property particularly if made in favour of a done possessing greater information who nevertheless withheld the facts."

\section{Similarly, Latham CJ stated: ${ }^{57}$}

"... if a donee is the moving spirit in the transaction of a gift, and the donor is of weak will or of poor mentality, a court of equity will set aside the gift unless it is shown that the donor understood the substance of what he was doing."

The better view, therefore, is that both gifts and bargains are subject to the doctrine of unconscionability. ${ }^{58}$ More recently, in Evans $v$ Lloyd ${ }^{59} \mathrm{HH}$ Judge Keyser QC (sitting as a judge of the High Court), after considering Langton, concluded that to exclude gifts from the scope of the doctrine would make its application turn on form over substance which was to be avoided in an equitable jurisdiction. ${ }^{60} \mathrm{He}$ also noted that the doctrine had been applied to gifts without inconvenience in the Australian and Republic of Ireland ${ }^{61}$ jurisdictions.

\subsection{The three governing elements}

The three key elements of the doctrine of unconscionable bargains may, therefore, be summarised as follows:

57 Wilton (n 55) 648. See also, Louth v Diprose (1993) 67 ALJR 95, 97 (High Court of Australia), where Brennan J stated: "gifts obtained by unconscionable conduct and gifts obtained by undue influence are set aside by equity on substantially the same basis."

${ }^{58}$ See further, D Capper, 'Unconscionable Bargains and Unconscionable Gifts' [1996] Conv 308. In Capper's view, gifts do not provide any distinction between undue influence and unconscionability. Indeed, it supports his premise that contractual imbalance provides merely an evidential function under both doctrines. In this connection, it has been held that the requirement of manifest disadvantage is not necessary for gifts: Geffen $v$ Goodman Estate [1991] 2 SCR 353, 378 (Wilson J). This must be right since otherwise it would be difficult to uphold gifts (which, by their very nature, are one-sided) under either doctrine.

59 [2013] EWHC 1725 (Ch).

${ }^{60}$ Ibid [52].

${ }^{61}$ See Prendergast $v$ Joyce [2009] IEHC 199. 
- Contractual imbalance (i.e. the bargain itself must be oppressive)

- Relational inequality (i.e. the complainant was in a position of bargaining weakness)

- Unconscionable conduct (i.e. the other party must have knowingly taken advantage of the complainant)

So far as contractual imbalance is concerned, the cases show that the complainant must have entered into a transaction which was substantively unfair, in that he received nothing or very little in return. In other words, the terms of the transaction are so unfair that they shock the conscience of the court. In Burch, for example, the crucial factor in the Court of Appeal's decision was the extreme substantive unfairness of the transaction which gave rise to "grave suspicion" and cried "aloud for an explanation". ${ }^{62}$ The second element (relational inequality) requires that the complainant be in some position of weakness (or special disadvantage) in relation to the other party. As we have seen, the phrase "ignorant and poor" in this context has been defined in the modern cases to mean someone who is not well educated and in a lower income group. In Alec Lobb Ltd $v$ Total Oil (Great Britain) Ltd, ${ }^{63}$ Peter Millett QC (sitting as a deputy High Court judge) stated ${ }^{64}$ that the doctrine was capable of applying "if one party has been at a serious disadvantage to the other, whether through poverty, or ignorance, or lack of advice, or otherwise, so that circumstances existed of which unfair advantage could be taken". It is apparent, for example, that inability to speak English, if taken advantage of, may come within the doctrine. ${ }^{65}$ The third element of the doctrine (unconscionable conduct) is also crucial to the granting of relief. In Hart $v O^{\prime}$ Connor, ${ }^{66}$ Lord Brightman identified two distinct meanings of unfairness in the context of a contractual transaction. First, a contract may be unfair because of the unfair manner in which it is brought into existence. A contract induced by undue influence is unfair in this sense (i.e. procedural unfairness). Alternatively, a contract may be described as unfair by reason of the fact that the terms of the contract are more favourable to one party than to the other (i.e. contractual imbalance). According to His Lordship, both procedural unfairness and contractual

\footnotetext{
62 Ibid 152 (Millett LJ).

63 [1983] 1 WLR 87.

${ }^{64}$ Ibid 94-95.

${ }^{65}$ See, Barclays Bank plc v Schwartz (1995) The Times, 2 August.

66 [1985] AC 1000 (PC).
} 


\section{UNDUE INFLUENCE: TOWARDS A UNIFYING CONCEPT OF UNCONSCIONABLITY?}

imbalance were necessary to relieve a party from a transaction. ${ }^{67}$ However, he also intimated that contractual imbalance may be so extreme as to raise a presumption of procedural unfairness (for example, undue influence or some other form of victimisation). This is also acknowledged by Millett LJ in Burch, where he suggested that, both in unconscionable bargain and undue influence cases, the court could "infer the presence of impropriety from the terms of the transaction itself" ${ }^{68}$

\section{THE COMMONWEALTH EXPERIENCE}

In the Commonwealth jurisdictions, the courts have tended to accept a more general doctrine of unconscionability. It will be convenient to examine briefly the position in Canada, Australia and New Zealand. Unlike the English courts, these jurisdictions have been far more open to the notion that a transaction can be unconscionable because the terms are considerably more advantageous to the stronger party who passively receives those advantages in the knowledge that the other (weaker) party is vulnerable. ${ }^{69}$ As we have seen, under English law, unconscionability normally requires that the stronger party has imposed the objectionable terms in a morally reprehensible manner, ${ }^{70}$ although the courts have also acknowledged that a contract may be so unfair (or one-sided) as to raise a presumption of procedural unfairness.

\subsection{Canada}

An early leading authority is Morrison $v$ Coast Finance $L t d,{ }^{71}$ which, interestingly, was cited by Lord Denning MR in Bundy $y^{72}$ as illustrative of his proposition that the doctrine of unconscionable transactions extends to "all cases where an unfair advantage has been gained by an

\footnotetext{
${ }^{67}$ Ibid 1018 .

68 [1997] 1 All ER 144 (CA) 153. See also, Portman Building Society v Dusangh [2000] 2 All ER (Comm) 221 (CA) 235, where Ward LJ refers to "an evidential assumption of wrongdoing" if the transaction itself cries out for an explanation.

${ }^{69}$ See, D Capper, 'The Unconscionable Bargain in the Common Law World' (2010) 126 LQR 403, 416.

${ }^{70}$ See for example, Multiservice Bookbinding Ltd v Marden [1979] Ch 84, 110 (Browne-Wilkinson).

${ }^{71}$ (1965) 55 DLR (2d) 710. For an overview, see Halsbury's Laws of Canada, Restitution, 2017 Reissue, (LexisNexis) 976-981.

72 [1974] 3 All ER 757 (CA) 764.
} 
unconscientious use of power by a stronger party against a weaker". In Morrison, an elderly widow with slender means was persuaded by two men to mortgage her home and lend the proceeds to them so that they could repay a loan to the first defendant lender and buy two cars from the second defendant. The British Columbia Court of Appeal held that the transaction was unconscionable and granted relief. The case is significant in that it sets out the material ingredients for a successful claim to set aside a contract on the ground of unconscionability. The two vital elements were: (1) proof of inequality in the positions of the parties arising out of ignorance, need or distress of the weaker, leaving him (or her) in the power of the stronger party; and (2) proof of substantial unfairness of the bargain thus obtained by the stronger party. Once these elements were satisfied, a presumption of fraud arose which could only be rebutted by showing that the bargain was fair, just and reasonable with no advantage taken. In the course of his judgment, Davey JA stated: ${ }^{73}$

"The equitable principles relating to undue influence and relief
against unconscionable bargains are closely related, but the
doctrines are separate and distinct. The finding here against undue
influence does not conclude the question whether the appellant is
entitled to relief against an unconscionable transaction."

In his Honour's view, ${ }^{74}$ a plea of undue influence attacked "the sufficiency of consent" whilst the doctrine of unconscionable bargains invoked "relief against an unfair advantage gained by an unconscientious use of power by a stronger party against a weaker".

Despite this initial reluctance to assimilate the two doctrines under one umbrella of unconscionability, it is significant that, since the English decision in Bundy, the Canadian courts have adopted the broader formulation of "inequality of bargaining power" enunciated by Lord Denning MR in that case as part of their law. In McKenzie $v$ Bank of Montreal ${ }^{75}$ for example, the Ontario High Court, applying Bundy, held that a bank, who had knowledge that the claimant had been acting under the undue influence of her partner, owed a duty of care to her to ensure that she appreciated and intended the consequences of the transaction.

\footnotetext{
73 Ibid 713 .

74 Ibid.

75 (1975) 55 DLR (3d) 641. See also, Buchanan v Canadian Imperial Bank of Commerce (1979) 100 DLR (3d) 624 (British Columbia Supreme Court); Bertolo v Bank of Montreal (1986) 33 DLR (4d) 610 (Ontario Court of Appeal).
} 
This meant providing the claimant with the necessary information and advice, or to see that she had obtained it. Since the bank had failed in that duty, the mortgage was set aside.

Indeed, some of the Canadian cases have gone further. Most notably, in Harry v Kreutziger ${ }^{76}$ another decision of the British Columbia Court of Appeal, Lambert JA propounded a broader test of unconscionability based on "community standards of commercial morality". He stated: ${ }^{77}$

"In my opinion, questions as to whether use of power was unconscionable, an advantage unfair or very unfair, a consideration was grossly inadequate, or bargaining power was grievously impaired, to select words from both statements of principle, the Morrison case and the Bundy case, are really aspects of one single question. That single question is whether the transaction, seen as a whole, is sufficiently divergent from community standards of commercial morality that it should be rescinded. To my mind, the framing of the question in that way prevents the real issue from being obscured by an isolated consideration of a number of questions ..."

In this case, the appellant, an elderly, inarticulate Indian man with limited education, who was also partially deaf, agreed to sell his fishing boat for $\$ 4,500$. In fact, the boat was worth $\$ 16,000$, largely because of a fishing licence attached to it. The buyer, a man of great business experience and with full knowledge of the true value of the boat, induced the sale by assuring the appellant that he could easily obtain another licence. Not surprisingly, the sale was set aside as an unconscionable bargain. The circumstances of the transaction revealed a "marked departure" from community standards of commercial morality. Significantly, this test has been applied in several subsequent Canadian authorities. $^{78}$

\footnotetext{
76 (1978) 95 DLR (3d) 231.

77 Ibid 241.

${ }^{78}$ See for example, A\&K Lick-a-Chick Franchises Ltd $v$ Cordiv Enterprises Ltd (1981) 119 DLR (3d) 44 (Nova Scotia Supreme Court). For a full review of the cases, see SR Enman, 'Doctrines of Unconscionability in Canadian, English and Commonwealth Contract Law’ (1987) 16 Anglo-American Law Review 191.
} 
A more traditional formulation of the doctrine, however, was applied in Cain $v$ Clarica Life Insurance Co, ${ }^{79}$ where Cote $\mathrm{J}$ outlined the following key elements as necessary to found relief:

"1. A grossly unfair and improvident transaction; and

2. The victim's lack of independent legal or other suitable advice; and

3. An overwhelming imbalance in bargaining power caused by the victim's ignorance of business, illiteracy, ignorance of the language of the bargain, blindness, deafness, senility, or similar disability; and

4. The other party's knowingly taking advantage of this."

\subsection{Australia}

There are several landmark cases in the Australian jurisdiction which call for comment. In Blomley $v$ Ryan ${ }^{80}$ an uneducated farmer, 78 years old, who was mentally and physically weak, suffering from the effects of intoxication, conveyed his farm to the purchaser who knew of his disabilities and the inadequacy of the price. The transaction was held to be unconscionable and the contract was set aside. McTiernan $J$ stated ${ }^{81}$ that "the essence of the fraud" was that "advantage was taken of weakness, ignorance and other disabilities ... and the contract was derived from such behaviour and it is an unfair bargain." In his view, the principle extended to "all cases in which the parties to a contract have not met upon equal terms." ${ }^{82}$ Fullagar $\mathrm{J}$ identified some of the circumstances adversely affecting a party which may induce the court to set aside the transaction. Among these, he listed "poverty or need of any kind, sickness, age, sex, infirmity of the body or mind, drunkenness, illiteracy or lack of education, lack of assistance or explanation where assistance or explanation is necessary" ${ }^{83}$ In his view, the common characteristic was that they placed one party at a serious disadvantage to the other.

79 (2005) 263 DLR (4th) 368 (Alberta Court of Appeal) [31]-[32]. These elements were applied in Lydian Properties Inc v Chambers (2009) 457 AR 211 (Alberta Court of Appeal).

${ }^{80}$ (1956) 99 CLR 362 (High Court of Australia).

${ }^{81}$ Ibid [386].

${ }^{82}$ Ibid.

${ }^{83}$ Bromley (n 80) Ibid 405. 


\section{UNDUE INFLUENCE: TOWARDS A UNIFYING CONCEPT OF UNCONSCIONABLITY?}

Another landmark decision is Commonwealth Bank of Australia $v$ Amadio, ${ }^{84}$ where Mason $\mathrm{J}$ concluded that the jurisdiction to set aside transactions as unconscionable arose "whenever one party by reason of some condition or circumstance is placed at a special disadvantage vis a vis another and unfair or unconscientious advantage is then taken of the opportunity thereby created." ${ }^{85}$ Thus, as under English law, three requirements were necessary to raise the equity: (1) an improvident arrangement; (2) inequality of bargaining power; and (3) an unconscientious taking of advantage of the party under a special disability. Interestingly, Mason $\mathrm{J}$ also considered ${ }^{86}$ that, whilst there was "some resemblance" between unconscionable conduct and undue influence, an important distinction was that:

"In the latter, the will of the innocent party is not independent and voluntary because it is overborne. In the former, the will of the innocent party, even if independent and voluntary, is the result of the disadvantageous position in which he is placed and of the other party unconscientiously taking advantage of that position."

He acknowledged, however, that the two doctrines were not mutually exclusive in the sense that only one of them could be available in a particular situation to the exclusion of the other. In his view: ${ }^{87}$

"Relief on the ground of unconscionable conduct will be granted when unconscientious advantage is taken of an innocent party whose will is overborne so that it is not independent and voluntary, just as it will be granted when such advantage is taken of an innocent party who, though not deprived of an independent and voluntary will, is unable to make a worthwhile judgment as to what is in his best interest."

A similar conclusion was reached by Deane J, who considered that the equitable principles relating to unconscionable dealing and undue influence were "closely related" but, nonetheless, "distinct" ${ }^{88}$ In his view,

\footnotetext{
84 (1983) 151 CLR 447 (High Court of Australia).

85 Ibid 462.

${ }^{86}$ Amadio (n 84) 461.

87 Ibid.

${ }^{88}$ Amadio (n 84) 474. See, generally, Halsbury's Laws of Australia Vol 6 para 110-5885: "Unlike undue influence, which like common law duress, looks to the
} 
undue influence looks to the quality of the consent of the weaker party whereas unconscionable dealing looks to the conduct of the stronger party "in attempting to enforce, or retain the benefit of, a dealing with a person under a special disability in circumstances where it is not consistent with equity or good conscience that he should do so". 89

It is submitted, however, that these distinctions are somewhat illusory. The doctrine of undue influence does, in fact, involve the wrongdoer in taking unconscientious advantage of an innocent party who is in a disadvantageous position. As Phang has stated, ${ }^{90}$ "under class 1 and class $2 \mathrm{~b}$ undue influence, it may be stated that the innocent party is often manipulated into a situation of disadvantage". And, as one Australian commentator has observed: ${ }^{91}$

"The parallels between presumed unconscionable conduct (contracting in the knowledge that the other party labours under a special disadvantage) and presumed undue influence (contracting in the knowledge that the other party reposes trust and confidence in one in the relevant sense) are significant. Both doctrines require sufficient awareness or perception on the part of the stronger party and, it is suggested, the tests for sufficient awareness should be the same in both cases. Both doctrines impose a similar duty: to ensure that the weaker party has formed an independent and informed judgment; this duty may be discharged by allowing the weaker party an opportunity to seek independent legal advice ... And, most importantly, both doctrines are designed to mitigate the risk of abuse by the stronger party of his position of special advantage. Abuse of a perceived position of special advantage is the thread that links these two equitable doctrines."

quality of the consent or assent of the weaker party, unconscionable dealing looks to the conduct of the stronger party in attempting to force, or retain the benefit of, a dealing with a person under a special disability or disadvantage in circumstances where it is not consistent with equity or good conscience that he or she should do so. On this basis, the jurisdiction in relation to unconscionable conduct is distinct from the jurisdiction in relation to undue influence, where the essential focus is on the position of the plaintiff rather than the conduct of the defendant."

${ }^{89}$ Amido (n 84) [474].

90 See A Phang, 'Undue Influence: Methodology, Sources and Linkages' [1995] JBL 552, 568.

91 See IJ Hardingham, 'The High Court of Australia and Unconscionable Dealing' (1984) 4 OJLS 275, 286. 


\section{UNDUE INFLUENCE: TOWARDS A UNIFYING CONCEPT OF UNCONSCIONABLITY?}

This, of course, reflects the view taken by Lord Denning MR in Bundy ${ }^{92}$ and his formulation of a general principle linking undue influence, unconscionable transactions (and other vitiating factors) under the "single thread" of inequality of bargaining power. In Amadio, the facts did not warrant any finding that the bank was in a confidential relationship with the parents since the latter relied on their son, not the bank, to advise them on the nature of the loan transaction. Had, however, the bank "crossed the line" into the area of confidentiality then, clearly, issues relating to a presumed undue influence would have arisen for consideration.

In another important decision, the High Court of Australia sought to apply the concept of unconscionability to a situation where a surety wife did not understand the purpose and effect of the guarantee she signed and there was a failure by the bank to explain properly the transaction to her. In National Australia Bank Ltd v Garcia,${ }^{93}$ the majority of the High Court, applying the earlier case of Yerkey $v$ Jones,${ }^{94}$ held that the lender had acted unconscionably in enforcing the guarantee against the wife because: (1) she did not understand the purpose and effect of the transaction; (2) she was a volunteer because she did not obtain any benefit from the transaction; (3) the lender was taken to have understood that, as a wife, she may have reposed trust and confidence in her husband in business matters and, therefore, to have understood that the husband may not have fully and accurately explained the effect of the transaction to her; and (4) the lender took no steps to explain the purport and effect of the transaction to her or to ascertain whether it had been explained to her by a competent, independent and disinterested stranger. The significance of this case is that the High Court rejected the English O'Brien approach (grounded in the notion of notice) in favour of a (revived) wife's "special equity" doctrine, which allowed her to set aside a guarantee on the grounds that she did not understand it and that its nature and effect had not been explained to her. This equity, however, was based, not on the status and abilities of married women, but rather (as in Etridge) the potential for abuse of trust within the marriage relationship. The element of notice, therefore, was only relevant in determining whether or not the lender knew, at the time of the guarantee, that the surety was married to the borrower. In effect, the decision in Garcia imposed a strict (primary) liability on lenders to disclose full and accurate information to wives who

\footnotetext{
92 [1974] 3 All ER 757 (CA) 765.

93 (1998) 194 CLR 395.

94 (1939) 63 CLR 649.
} 
act as sureties for their husband's debts. The High Court also intimated that equity's special protection could extend to other relationships (for example, heterosexual or homosexual cohabitees).$^{95}$

Finally, reference should be made to Louth $v$ Diprose,${ }^{96}$ where the majority of the High Court of Australia held that the respondent was entitled to recover a substantial gift of money which he had made to a woman (the appellant) with whom he had had a romantic relationship for several years. In fact, the respondent, had been infatuated with the appellant and it was apparent that the latter had exploited his emotional dependence on her. When she needed a place to live, he bought a house for her and had it conveyed into her sole name. The judgment of Brennan $\mathrm{J}$ is of particular interest because he sought to assimilate the court's jurisdiction to set aside gifts procured by unconscionable conduct with the "similar" jurisdiction to set aside gifts procured by undue influence. In his view, ${ }^{97}$ both depended upon the effect of influence (presumed or actual) improperly brought to bear by one party to a relationship on the mind of the other whereby the other disposes of his property. This similarity "gives to cases arising in the exercise of one jurisdiction an analogous character in considering cases involving the same points in the other jurisdiction." The effect of this judgment is substantially to merge the concept of unconscionability with that of undue influence.

\subsection{New Zealand}

In Archer $v$ Cutler, ${ }^{98}$ a contract for the sale of 10 acres of land was executed by the parties at the defendant's residence. Medical evidence later showed that the defendant was suffering from senile dementia. Although living alone, she was incapable of managing her own affairs and unable to keep proper appraisals of facts and conscious judgments on important matters. The claimant did not know of the defendant's impaired mental condition, nor of its effect on her ability to understand the bargain

\footnotetext{
95 See further, M Bryan, 'Setting Aside Guarantees: Reviving and Old Equity' [1999] LMCLQ 327; M Brown, 'Suretyship and Marriage: Notice V Unconscionability' (2000) RLR 152; E Stone, 'Infants, Lunatics and Married Women: Equitable Protection in Garcia v National Australia Bank' (1999) 62 MLR 604; A Finlay, 'Australian Wives are Special: Yerkey v Jones Lives On' [1999] JBL 361.

96 (1993) 67 ALJR 95.

${ }^{97}$ Ibid 98.

98 [1980] 1 NZLR 386 (Supreme Court of Auckland).
} 


\section{UNDUE INFLUENCE: TOWARDS A UNIFYING CONCEPT OF UNCONSCIONABLITY?}

she had entered into. The claimant was also unaware that the agreed price represented a substantial undervalue for the land. The Supreme Court of Auckland held, nevertheless, that the defence of unconscionable bargain was established. The decision clearly went further than the English and Australian authorities, which require that the stronger party actually take advantage of his position. Not surprisingly, therefore, in Hart $v$ $O^{\prime} C_{0}$ nnor, ${ }^{99}$ the Privy Council (on appeal from the New Zealand Court of Appeal) held, overruling the Archer case, that a contract could not be set aside as an unconscionable bargain where the purchaser had acted completely innocently and was not guilty of any unconscionable conduct. Subsequent New Zealand cases have adopted this approach, albeit with some reluctance.

In Nichols $v$ Jessup (No 2), ${ }^{100}$ the claimant sought specific performance of an agreement between himself and the defendant to grant mutual rights of way over their respective properties so as to improve the road access to the claimant's rear section. The High Court held, ostensibly applying the Hart $v O^{\prime}$ Connor ruling, that because the claimant was aware of the defendant's weaknesses in regard to financial and property matters, which was manifestly one-sided, the agreement could properly be set aside as unconscionable. Significantly, as the High Court itself conceded, there was no evidence in this case to suggest that the claimant had consciously intended to take advantage of the defendant's ignorance when she was persuaded to agree to his proposal regarding the rights of way. In the absence of any moral fraud, therefore, it has been suggested by one commentator ${ }^{101}$ that the transaction should have been upheld.

In Contractors Bonding Ltd v Snee, ${ }^{102}$ the Wellington Court of Appeal also applied Hart $v O^{\prime}$ Connor, holding that equity will only intervene to deprive parties of their contractual rights where they have unconscionably obtained benefits or have accepted benefits in unconscionable circumstances (i.e. where they would be acting unconscientiously in receiving or retaining their bargain). In this case, the complainant was under a special disability at the time of contracting due to her mental capacity resulting in a defective understanding of her affairs and of the transaction. That, however, in itself, was not enough to establish that the company was guilty of fraud. It had no knowledge of, and could not be

\footnotetext{
99 [1985] AC 1000 (PC).

${ }^{100}$ [1986] 1 NZLR 237 (High Court of Auckland).

${ }^{101}$ See further, N Bamforth, 'Unconscionability as a Vitiating Factor' [1995] LMCLQ 538.

102 [1992] 2 NZLR 157 (Wellington Court of Appeal).
} 
expected to have any awareness of, her incapacity and, moreover, had no reason to believe that she was under the influence of her son. In addition, the guarantee and mortgage over her house were standard commercial transactions with no unusual features which the company was required to disclose to the complainant. The transaction, therefore, could not be characterised as improvident (amounting to contractual imbalance) nor was there any evidence of unfairness or overreaching on the part of the company. The result, therefore, was that the company could rely on its mortgage.

Interestingly, in Walmsley $v$ Christchurch City Council, ${ }^{103}$ Hardie Boys J opined that the concepts of undue influence and unconscionability were "different concepts, although both are founded on fraud, in the sense of an unconscionable use of power". In Bowkett $v$ Action Finance $L t d,{ }^{104}$ Tipping $\mathrm{J}$ set out the following circumstances which, in his view, would normally be present when a court finds an unconscionable bargain: (1) the weaker party is under a considerable disability; (2) the stronger party knows or ought to know of that disability; (3) the stronger party has victimised the weaker in the sense of taking advantage of the weaker party's disability, either by active extortion of the bargain, or passive acceptance of it in circumstances where it is contrary to conscience that the bargain should be accepted; (4) there is a marked inadequacy of consideration and the stronger party either knows or ought to know that to be so: and (5) there is some procedural impropriety either demonstrated or presumed from the circumstances. In Tipping J's view, ${ }^{105}$ not all elements need necessarily be shown, but elements 1-3 were crucial, as there could not be an unconscionable bargain without a disability in the weaker party and knowledge and taking advantage thereof by the stronger party. $\mathrm{He}$ also intimated that absence of independent advice was a frequent feature of unconscionable bargain cases. What was important, however, was the "cumulative weight of all relevant points" in determining "the ultimate question" as to whether the bargain could properly be characterised as unconscionable so that equity should intervene.

Tipping $\mathrm{J}$ had a further opportunity to formulate the relevant principles in Gustav \& Co Ltd v Macfield Ltd, ${ }^{106}$ where he stated: ${ }^{107}$

\footnotetext{
103 [1990] 1 NZLR 199 (Christchurch High Court).

104 [1992] 1 NZLR 449 (Christchurch High Court).

105 Ibid 460.

106 [2008] NZSC 47 (Supreme Court of New Zealand).

107 Ibid [6]. See also, generally, The Laws of New Zealand, Vol 26, Specific Performance, p 22, para 16, (Butterworths); Service 87, at 660.002, (LexisNexis).
} 
"Equity will intervene when one party in entering into a transaction, unconscientiously takes advantage of the other. That will be so when the stronger party knows or ought to be aware, that the weaker party is unable adequately to look after his own interests and is acting to his detriment. Equity will not allow the stronger party to procure or accept a transaction in these circumstances. The remedy is conscience-based and, in qualifying cases, the Court intervenes and says that the stronger party may not take advantage of the rights acquired under the transaction because it would be contrary to good conscience to do so."

As Capper ${ }^{108}$ has observed, "the approach to the unconscionable bargain in New Zealand is practically indistinguishable from the approach in Australia."

\section{AN UNDERLYING CONCEPT OF UNCONSCIONABILITY?}

Undoubtedly, there is a close relationship between the principles relating to undue influence and unconscionable bargains. Should the two be fused within one all-embracing doctrine? Academic commentators differ on whether this would be a useful process. Capper, in an influential article,${ }^{109}$ has argued that the two doctrines share three common features: (1) inequality in the bargaining positions of the parties (i.e., relational inequality): (2) transactional imbalance; and (3) unconscionable conduct on the part of the defendant. He acknowledges, however, that these features are mere "distillations from the cases, rather than judicially determined principles. ${ }^{110}$

So far as the first element is concerned, this is present in presumed undue influence cases, in so far as the complainant must prove the existence of a relationship under which he (or she) generally reposed trust and confidence in the wrongdoer. Relational inequality is always present (by definition) in actual undue influence cases. And, as we have seen, the requirement is also to be found in unconscionability cases in that the

\footnotetext{
108 See D Capper, 'The Unconscionable Bargain in the Common Law World' (2010) 126 LQR 403.

109 See D Capper, 'Undue Influence and Unconscionability: A Rationalisation' (1998) 114 LQR 479.

${ }^{110}$ See D Capper, 'The Unconscionable Bargain in the Common Law World' (2010) 126 LQR 403, 417.
} 
complainant must be shown to be suffering from some special disadvantage to warrant equity's intervention. Capper concludes that "the kind of relational inequality sufficient to support a case of unconscionability is clearly very broad and there cannot be any difficulty in fitting cases of undue influence within it." 111

Turning to transactional imbalance, Capper concedes that this requirement does not feature in the actual undue influence category, which requires mere proof of actual coercion over the weaker party. His argument, however, is that transactional imbalance (i.e. the bargain itself must be oppressive) is not an essential requirement of any undue influence or unconscionability case (albeit invariably present), but simply "powerful evidence in support of relational inequality and unconscionable conduct, which are the true invalidating grounds." 112 On this point, he (like other commentators) doubts whether manifest disadvantage should be an essential feature of the presumed undue influence category. The better view, as we have seen, is that manifest disadvantage should take the form of a purely evidential consideration when the wrongdoer is seeking to rebut the presumption of undue influence. In other words, there is no reason why a complainant should not rely on the doctrine even though the transaction itself is objectively reasonable. Take, for example, a solicitor who buys his client's house at a fair price. The requisite relationship of confidence would exist between the parties (i.e. relational inequality) and there seems no reason why the presumption of undue influence should not arise requiring the solicitor to show that the client had formed an independent and informed judgment. The mere fact that the price was fair would not be enough to rebut the presumption because "there might be all sorts of reasons, apart from the price, why the client did not want to sell his house." 113 Transactional imbalance, according to Capper, is also not an essential precondition to a finding of unconscionability. Although many of the cases do involve sales at an undervalue and other forms of contractual imbalance, this is not always the case. ${ }^{114} \mathrm{He}$ concludes that "if

\footnotetext{
${ }^{111}$ Ibid 486.

112 Ibid.

${ }^{113}$ National Westminster Bank plc v Morgan [1983] 3 All ER 85 (CA) (Dunn LJ).

${ }^{114} \mathrm{He}$ cites, for example, the Australian case of Blomley $v$ Ryan (1956) 99 CLR 362, where the High Court of Australia held that the decisive factors of unconscionability were the seller's mental weakness and the purchaser's unconscionable conduct. In that case, the property was sold for $\$ 25,000$, its true value being not significantly more $(\$ 33,000)$. Capper also cites Deane $\mathrm{J}$, in Commonwealth Bank of Australia v Amadio (1983) 151 CLR 447, 475, who
} 


\section{UNDUE INFLUENCE: TOWARDS A UNIFYING CONCEPT OF UNCONSCIONABLITY?}

manifest disadvantage assumes the evidential role recommended for it in respect of presumed undue influence, then assimilation with actual undue influence and unconscionability becomes relatively easy." 115

Finally, so far as unconscionable conduct is concerned, this, according to Capper, is a requirement of both doctrines. It is clearly evident in actual undue influence cases and is an essential feature of unconscionability cases. In his view, "actual undue influence (without pressure) is only different from presumed undue influence in so far as what is presumed in the latter is affirmatively proved in the former." 116 On this reasoning, therefore, both actual and presumed undue influence should be subsumed under a general doctrine of unconscionability. Although, in the presumed undue influence category, coercion and abuse by the defendant is less easy to discern, nevertheless, many of the cases on unconscionable dealing, as we have seen, also concern little more than passive acceptance of benefits received under unconscionable circumstances. ${ }^{117}$

Not all commentators, however, have agreed with this attempt at rationalisation. Birks and Chin, ${ }^{118}$ for example, have argued that undue influence and unconscionability are essentially separate and distinct concepts and favour preserving the distinction between the two. They regard undue influence as being "plaintiff-sided" and concerned with the weakness of the claimant's consent owing to an excessive dependence upon the defendant, and unconscionability as being "defendant-sided" and concerned with the defendant's exploitation of the claimant's vulnerability. In support of this contention, they draw attention to two features of the presumed undue influence cases. First, many of the presumed undue influence cases do not involve any conscious wrongdoing on the part of the defendant - on the contrary, the evidence shows merely a passive receipt of benefits arising from the transaction.

opined that, whilst most unconscionability cases involved inadequacy of consideration, this was not essential.

${ }^{115}$ D Capper, 'Undue Influence and Unconscionability: A Rationalisation' (1998) 114 LQR 479, 500.

${ }^{116}$ Ibid 493.

117 See for example, Hart $v$ O'Connor [1985] AC 1000 (PC) 1024 (Lord Brightman): “... it is victimisation, which can consist either of the active extortion of a benefit or the passive acceptance of a benefit in unconscionable circumstances."

${ }^{118}$ See P Birks and NY Chin, 'On the Nature of Undue Influence' in J Beatson and D Friedmann (eds), Good Faith and Fault in Contract Law (Clarendon Press 1995); J Devenney and A Chandler, 'Unconscionability and the Taxonomy of Undue Influence' [2007] JBL 541. 
Secondly, where the presumption of undue influence is raised, it is open to the defendant to rebut the presumption by showing that the complainant had acted freely and with an independent will. This requirement, therefore, is directed at the issue of consent and is not concerned with any wrongdoing on the part of the defendant. Some writers, however, have questioned this analysis. Thus, Bigwood ${ }^{119}$ has argued that undue influence is defendant/conduct-based in both its concerns and orientation. In his view, both undue influence and unconscionable dealings concern a form of exploitation, although the source of the claimant's vulnerability is different in each case. Despite this difference between the two concepts, he concludes that "there is no logical reason" why the jurisdiction of unconscionable dealings could not include undue influence.

What is also overlooked, it is submitted, in Birks and Chin's analysis, is that the passive acceptance of benefits, as we have seen from the Commonwealth experience, may itself be unconscionable in the circumstances of a particular case. ${ }^{120}$ It does not necessarily have to involve wicked exploitation. As Capper has pointed out, many of the unconscionability cases have this common feature and, therefore, there seems little reason why undue influence and unconscionability should not be assimilated. Any such new (combined) doctrine would not be either specifically "plaintiff-sided" or specifically "defendant-sided" (as Birks and Chin) maintain because "the stronger the plaintiff-sided the weaker the defendant-sided factor needs to be and vice versa, although a degree of unconscionable conduct would be present in all cases since the passive receipt of benefits flowing under a seriously unbalanced transaction where the plaintiff was clearly in an unequal relationship with the defendant would count as unconscionable conduct." 121

This unifying doctrine of unconscionability could also be extended to embrace the liability of a third party lender in circumstances where it has actual or constructive notice that the loan transaction is tainted with undue influence, misrepresentation or some other equitable wrong. Thus, in

119 See R Bigwood, 'Undue Influence: Impaired Consent or Wicked Exploitation' (1996) 16 OJLS 503.

${ }^{120}$ See J Devenney and A Chandler, 'Unconscionability and the Taxonomy of Undue Influence' [2007] JBL 541.

${ }^{121}$ D Capper, 'Undue Influence and Unconscionability: A Rationalisation' (1998) 114 LQR 479, 500. Capper also makes the point that, since the House of Lords' ruling in Royal Bank of Scotland v Etridge (No 2) [2002] AC 773, undue influence is clearly concerned not just with lack of consent but also with the defendant's unconscionable conduct: see, D Capper, 'The Unconscionable Bargain in the Common Law World' (2010) 126 LQR 403, 417-418. 


\section{UNDUE INFLUENCE: TOWARDS A UNIFYING CONCEPT OF UNCONSCIONABLITY?}

Australia, as we have seen, if a lender has the requisite degree of knowledge of an unconscionable transaction (for example, between a husband and wife), it will itself be treated as acting unconscionably in relying on the transaction. A good illustration is also to be found from the Canadian jurisdiction in Shoppers Trust Co v Dynamic Homes Ltd. ${ }^{122}$ Here, the husband obtained a large loan from the claimant which was secured by a mortgage over the family home, which was owned solely by the wife. The husband had persuaded her to sign the documents at the offices of a solicitor who was acting for both the claimant and the third party. The wife was illiterate, had virtually no knowledge of her husband's business affairs and was fearful of her husband. The solicitor did not tell her that there was no legal requirement for her to sign, what the consequences of her signing would be, or that she should obtain independent advice. The Ontario Court held that there was a fiduciary relationship between the solicitor and the wife, which obliged the former to ensure that the wife fully understood the nature and consequences of her actions and to advise her to seek independent advice. The transaction was unconscionable because it was improvident (the wife received no benefit under the mortgage) and also because the husband (and the solicitor) had taken advantage of their dominant position over the wife. Significantly also, it was unconscionable to permit the claimant (as lender) to take advantage of the mortgage in the absence of proper independent advice. Although admittedly such an approach still depends on notice (and, therefore, broadly similar to the test enunciated by the House of Lords in Barclays Bank v O'Brien), ${ }^{123}$ "it focuses more directly upon the unconscionable conduct of the bank instead of the indirect test of notice of the undue influence of a third party". ${ }^{124}$

\section{CONCLUSION}

A radical overhaul of the doctrines of undue influence and unconscionable dealings, with a view to providing a single, coherent principle justifying equity's intervention to prevent the exploitation of the vulnerable, is much needed.

First, it can be argued that the current division of undue influence into two distinct categories (with the further refinement of the presumed

\footnotetext{
122 (1993) 96 DLR (4d) 267 (Ontario Court).

123 [1993] 4 All ER 417 (HL).

${ }^{124}$ D Capper, 'Undue Influence and Unconscionability: A Rationalisation' (1998) 114 LQR 479, 499.
} 
category into class $2 \mathrm{a}$ and $2 \mathrm{~b}$ cases) is unnecessarily technical and complex. The additional element in the presumed undue influence cases (both class $2 \mathrm{a}$ and $2 \mathrm{~b}$ ) of the need to show that the transaction was manifestly disadvantageous to the complainant has only added to this complexity and, as we have seen, has been criticised both academically and judicially. A simplified doctrine (which would get rid of these artificial categories) could be achieved, as Capper has suggested, by bringing together the common threads of: (1) relational inequality; (2) transactional imbalance; and (3) unconscionable conduct under one unified concept of unconscionable use of power.

Secondly, the adoption of a universal umbrella of unconscionable conduct has the advantage of affording the courts with a greater degree of flexibility in determining the outcome of a particular case. This was recognised by Nourse LJ in Bank of Credit and Commerce International (Overseas) Ltd $v$ Akindele, ${ }^{125}$ in the context of liability for knowing receipt, where he stated ${ }^{126}$ that a single test based on unconscionability ought to avoid the difficulties of "definition and allocation to which the previous categorisations [of knowledge] have led". Significantly, his Lordship also considered that such a test would make it easier for the courts to give common-sense decisions in the commercial context, in which most knowing receipt claims are made.

Thirdly, there is much to be said, as we have seen, for aligning undue influence with the related doctrine of unconscionable bargains. The two doctrines have common characteristics and it seems unduly artificial to treat them as distinct and separate claims arising, in many cases, out of the same set of facts. In particular, unconscionable conduct is already clearly evident in actual undue influence cases and is (by definition) an essential feature of unconscionable bargain cases. Although, in the presumed undue influence category, coercion and abuse may not always be present, nevertheless, many of the cases on unconscionable dealing also concern (as we have seen) little more than passive acceptance of benefits received under unconscionable circumstances. The resultant confusion has resulted in several cases being characterised as falling under undue influence instead of being treated as cases of unconscionability. ${ }^{127}$ The degree of overlap between the two doctrines, as well as the potential for confusion

\footnotetext{
125 [2001] Ch 437 (CA).

126 Ibid 455.

${ }^{127}$ See for example, Lloyds Bank Ltd v Bundy [1974] 3 All ER 757 (CA).
} 


\section{UNDUE INFLUENCE: TOWARDS A UNIFYING CONCEPT OF UNCONSCIONABLITY?}

in terms of bringing the appropriate litigation, has prompted Moore ${ }^{128}$ to observe recently:

"A single principle which rescinds a contract made by a party exploiting seriously constrained decisional autonomy of the other would unify yet faithfully preserve the rationale and operation of the discrete doctrines of ... undue influence, and unconscionability. Recognising it would enhance the law's coherence, clarify and streamline invalidity claims, and facilitate their consistent adjudication."

Fourthly, as noted earlier, the notion of unconscionability could easily be extended to embrace the liability of a third party in circumstances where it has actual or constructive notice that the loan transaction is tainted with an equitable wrong. Thus, the requisite degree of knowledge of an unconscionable transaction (for example, between a husband and wife) could itself be treated as acting unconscionably in relying on the transaction. This, it is submitted, would provide a welcome degree of symmetry between say, a wife's right to have a transaction set aside as against her husband on the grounds of her husband's undue influence and the unenforceability of the transaction against a third party bank or other lender who itself had acted unconscionably in relation to the transaction.

Finally, there is the more general point that an assimilation of undue influence with unconscionable bargains would reflect the growing judicial trend towards accepting unconscionability as a useful unifying tool in modern trust law. As we have seen, the notion of unconscionable dealing as an underlying principle has already been adopted in the context of proprietary estoppel, knowing receipt liability, imperfect transfers of property, joint venture arrangements, secret trusts and mutual wills. The lesson here is that, in each of these contexts, the principle of unconscionability has provided the courts with the opportunity not just to rationalise the underlying nature of liability but, more importantly, to provide a valuable contribution in defining its precise reach and scope. As Delany and Ryan have concluded: ${ }^{129}$

\footnotetext{
${ }^{128}$ See M Moore, 'Why Does Lord Denning's Lead Balloon Intrigue Us Still? The Prospects of Finding a Unifying Principle for Duress, Undue Influence and Unconscionability' (2018) 134 LQR 257, 284.

${ }^{129}$ See H Delany and D Ryan, 'Unconscionability: A Unifying Theme in Equity' (2008) Conv 401, 436.
} 
"In the final analysis, then, it seems fittingly ironic that a unifying theme of the use of the unconscionability principle across a wide spectrum of very different contexts is that this allegedly impenetrable and hopelessly obscure principle should itself emerge as a clarifying force, casting fresh light upon and signalling new directions in equitable relief."

One obvious objection to any such process of amalgamation is the notion that this would lead to considerable uncertainty in our law. The uncertainty argument should not, however, be overstated. As with most other doctrines, a broader notion of unconscionability in the context of undue influence and unconscionable bargains would inevitably lead to the laying down of more specific guidelines for determining its application. At the same time, there would be a more systematic approach to the development of the requisite principles which would avoid the current overlap and confusion arising from two related, but currently distinct doctrines. Phang puts the matter succinctly: ${ }^{130}$

"If, indeed, this approach of amalgamation or consolidation is adopted, the many problems pertaining to linkages both amongst the various categories of undue influence as well as amongst the doctrines of ... undue influence and unconscionability would vanish, and courts could set about the task of focusing their attention on bringing the new doctrine to legal maturity."

Capper also has addressed the uncertainty argument cogently: ${ }^{131}$

"A merged doctrine of undue influence/unconscionable bargain would not, it is submitted, generate further uncertainty than exists already in the common law. On the contrary, by allowing the courts to make a fresh start with conceptually clear principles, a much more functional doctrine could be created by judicial decisions which begin from the same sensible premises."

A good example can be taken from the emerging doctrine of knowing receipt liability. Here, recent case law has sought to clarify the degree of

\footnotetext{
${ }^{130}$ See A Phang, 'Undue Influence: Methodology, Sources and Linkages' [1995] JBL 552, 571.

${ }^{131}$ See D Capper, 'The Unconscionable Bargain in the Common Law World' (2010) 126 LQR 403, 419.
} 


\section{UNDUE INFLUENCE: TOWARDS A UNIFYING CONCEPT OF UNCONSCIONABLITY?}

fault or culpability necessary to trigger the doctrine. In Credit Agricole Corp and Investment Bank v Papadimitriou, ${ }^{132}$ Lord Sumption observed ${ }^{133}$ that "whether a person claims to be a bona fide purchaser of assets without notice of a prior interest in them, or disputes a claim to make him accountable as a constructive trustee on the footing of knowing receipt, the question of what constitutes notice or knowledge is the same". Thus, a party will be liable for knowing receipt where he should either have appreciated that a proprietary right existed, or have made inquiries or sought advice which would have revealed the probable existence of such a right. ${ }^{134}$ Moreover, inquiries must be made if there is a serious possibility of a third party having such a right, or if the facts are such as to give serious need to question the propriety of the transaction. ${ }^{135}$ As one commentator ${ }^{136}$ has observed, this guidance is not without significance in helping "to resolve some of the uncertainty about when a bank will be liable to account as a knowing recipient and ... contribut[ing] to a better understanding of what is unconscionable in this context".

The point here is that, although the concept of unconscionability may be expressed in fairly broad terms, the courts would exercise the new jurisdiction according to well-defined principles. This, as we have seen, is the approach taken in the Commonwealth jurisdictions, where the courts do not administer a general power to set aside transactions simply because, in the eyes of the judiciary, they appear to be harsh or unfair. On the contrary, far from acting in a wholly discretionary function, the courts have formulated specific tests for determining when a transaction should be set aside for unconscionability. There is no reason to suppose that a similar approach would not be adopted in this country. If, however, the English courts are reluctant to undertake what is perceived to be essentially a function of Parliament in developing the law, ${ }^{137}$ serious thought should be given to rationalising this area of law by means of legislative intervention. ${ }^{138}$

\footnotetext{
132 [2015] UKPC 13 (PC).

133 Ibid [33].

134 Papadimitriou (n 132) [18] (Lord Clarke).

135 Papadimitriou (n 132) [20] (Lord Clarke).
}

136 See R Pearce, 'When Must a Bank Repay Stolen Funds?' [2015] Conv 521, 528-529.

${ }^{137}$ See the observations of Lord Scarman in National Westminster Bank plc $v$ Morgan [1985] 1 All ER 821 (HL) 823.

138 English law has already moved some way to accepting substantive unconscionability in statutory form under the Unfair Terms in Consumer 
THE DENNING LAW JOURNAL

Contracts Regulations 1999 (formerly 1994). In the United States, a broad doctrine of substantive unconscionability is partly statutory, deriving from article 2-302 of the Uniform Commercial Code, and also common law based in those states where the Code does not apply. 